\title{
Unique applied glaciology challenges of proglacial mining
}

\author{
William Colgan, Henrik Højmark Thomsen and Michele Citterio
}

The glaciology group at the Geological Survey of Denmark and Greenland (GEUS) has a tradition of applied glaciology consulting for hydropower projects in Greenland (Weidick \& Thomsen 1982; Braithwaite \& Olesen 1988; Ahlstrøm et al. 2008). This includes assessments for the hydropower plants now operating at Ilulissat and Nuuk (Braithwaite \& Thomsen 1989; Thomsen et al. 1989; 1993), as well as the outburst potential of ice-dammed lakes such as Qorlortorsuup Tasia (Mayer \& Schuler 2005). Several factors, including long term increases in global resource demand, increasing air temperatures and glacier retreat due to climate change, and improved mining and prospecting techniques may now improve the economic feasibility of mining in Greenland (Colgan \& Arenson 2013). Given that over $80 \%$ of Greenland is ice-covered, mining projects in Greenland often occur in 'proglacial' settings, meaning adjacent to, or close to, an ice margin. The Isukasia, Kvanefjeld, Maarmorilik and Malmbjerg prospects exemplify resource development in proglacial settings in Greenland.

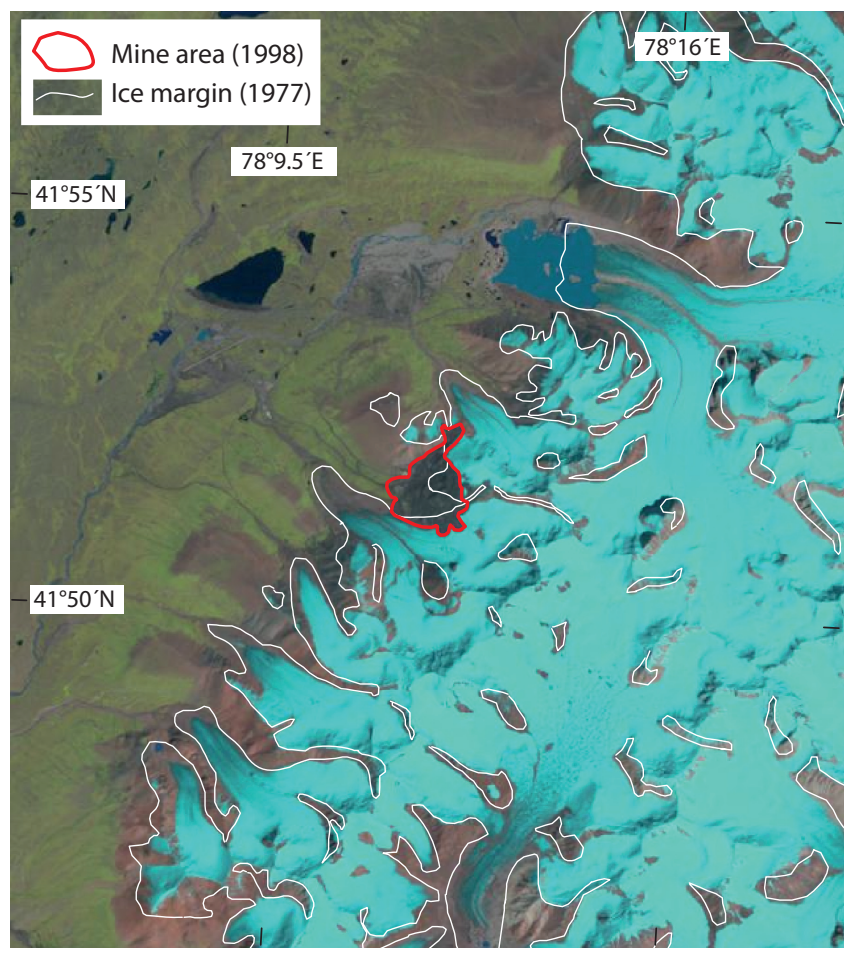

Fig. 1. Kumtor Mine, Kyrgyzstan. Historic ice margins and contemporary mine areas overlaid on 1998 (left) and 2014 (right) Landsat images. 


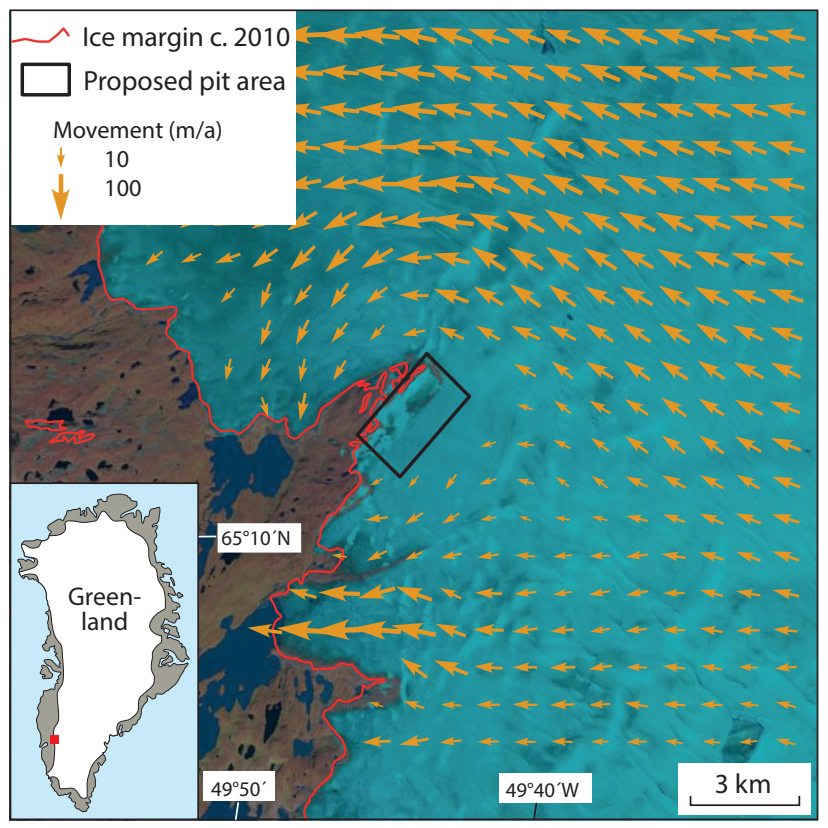

Fig. 2. The potential 'Isua' mine, Greenland, approved in 2013. Contemporary ice margins, proposed approximate pit area, and winter 2005/06 ice surface velocity vectors (Joughin et al. 2010). The background is a 2014 Landsat image.

\section{Unique Challenges}

It can be difficult to quantify and manage supraglacial meltwater runoff near the ice sheet margin. In southern Greenland, the annual ice melt (or 'ablation') can exceed $8 \mathrm{~m}$ water equivalent per unit area per melt season (Fausto et al. 2012). By comparison, the record annual rainfall on Earth is $c .12 \mathrm{~m}$ water equivalent in Meghalaya, India. In Greenland, however, the annual meltwater runoff is concentrated during a relatively brief summer melt season. During the melt season, water-saturated snowpacks are susceptible to slushflows, which can damage infrastructure both on, and adjacent to, glaciers (Smart et al. 2000). While surface mass-balance parameters generated by regional climate models can be calibrated with in situ data to assess the magnitude and spatial distribution of meltwater production (van As et al. 2014), estimates of the runoff that drains to any given proglacial site are very sensitive to the delineation of the supraglacial catchment areas (Arenson \& Colgan 2015). Uncertainty in the catchment delineation over the relatively flat ice sheet can easily contribute to $50 \%$ uncertainty in runoff (Rennermalm et al. 2013). Recent work has also demonstrated that supraglacial streams regularly breach local topographic divides, making it difficult to justify the application of strictly elevation-dependent terrestrial water routing algorithms to the ice sheet (Smith et al. 2015). Manual delineation of supraglacial catchments from high-resolution imagery is a time-consuming, but more accurate, alternative (Thomsen et al. 1989).

It is also important to assess the subglacial water flow reaching any given proglacial site, as the vast majority of meltwater 'runoff' produced on the surface of the ice sheet enters the en- and subglacial networks prior to discharge at the ice sheet margin (Smith et al. 2015). Analogous to terrestrial groundwater flow, the en- and subglacial hydrologic networks of the ice sheet have traditionally been conceptualised as saturated porous flow, whereby the en- and subglacial water flow is governed by hydraulic potentiometric surfaces that can be predicted using ice geometry (Lewis \& Smith 2009). Recent observations, however, indicate that channelised subglacial drainage and non-trivial head fluctuations extend tens of kilometres inland beneath the ice sheet (Chandler et al. 2013). Unlike groundwater flow through rock or sediment, the transmissivity of channelised flow in glacier ice can change rapidly, within hours or days, in response to both frictional melting along conduit walls and opening or closing due to viscous creep. As supraglacial lakes
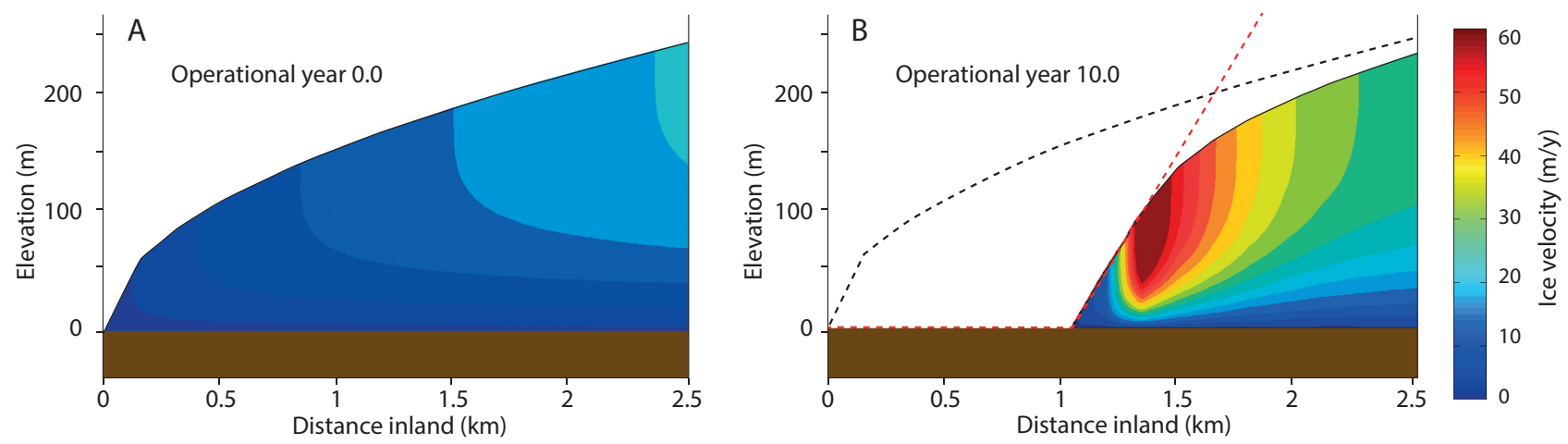

Fig. 3. Cross-sections of a glacier tongue with ice velocities (m/year). A: The glacier tongue has an undisturbed profile in operational year 0. B: After 10 years of excavation the ice wall has a gradient of 33\%. The ice velocities have increased from $10-20 \mathrm{~m} /$ year to $>60 \mathrm{~m} /$ year at the crown. The complete animation is available at www.williamcolgan.net/som/CRENG113 (Colgan 2014). 
can catastrophically release large volumes of meltwater (c. $10^{9} \mathrm{l}$ ) into the subglacial network via crevasse hydrofracture (Liang et al. 2012), there is a strong impetus to understand the preferential subglacial drainage routes in the vicinity of any given proglacial site.

Glacier ice movement can be so imperceptible over shorter time scales (hours to days) that glacier ice is commonly, but not strictly correctly, characterised as a solid. Over longer time scales (years to decades), the true non-Newtonian fluid character and appreciable movement of ice becomes evident (Colgan \& Arenson 2013). The creep of glacier ice under gravitational stress can cause operational difficulties due to ice movement beneath or against infrastructure, such as waste dumps and processing facilities (Citterio et al. 2009). An exceptionally challenging task is to forecast ice flow into open ice pit excavations. Due to the non-linear dependency of ice velocity on both ice thickness and surface gradient, the excavation of an open ice pit increases subsequent ice flow into the open ice pit (Colgan 2014). Perturbation of a natural glacier profile into an artificial ice wall with a gradient of $33 \%$ can increase crown velocities by an factor of five (Fig. 3). Open ice pits therefore require continuous excavation of substantial ice volumes to maintain pit geometry. Over the lifecycle of a proglacial mine, this may require excavating several times the ice volume of an open ice pit itself. Unlike conventional open pits in hard rock, the relative rapidity with which ice benches deform means that even temporary stoppages in ice excavation can adversely affect ice pit shape and flow (Els 2012).

The establishment and maintenance of supraglacial access roads are often critical elements of proglacial mining projects (Citterio et al. 2009). Traversing the relatively subdued topography of a glacier can be preferable to traversing the relatively severe topography of proglacial areas with abundant rivers and erratics (Fig. 4). In addition to potential crevasse hazards, supraglacial access roads can be compromised due to horizontal and vertical ice movement and differential surface ablation. While horizontal ice movement is readily observable by satellite (Fig. 2), vertical ice movement can be heterogeneous over short distances, where compressive and extensional flow result in opposing vertical movements via thrust- and slip-faulting along ice fractures (Nye 1952). It is desirable to establish a metre-scale aggregate, supraglacial road bed followed by continual grading in order to minimise the influence of heterogeneous vertical ice movements. This also improves road stability by keeping the ice beneath a road frozen throughout the year. However, active suppression of ablation beneath a supraglacial road results in perching of a road above the surrounding glacier surface (Davis 1967). Perching and consequent shoulder slumping hazards make roads that trav-

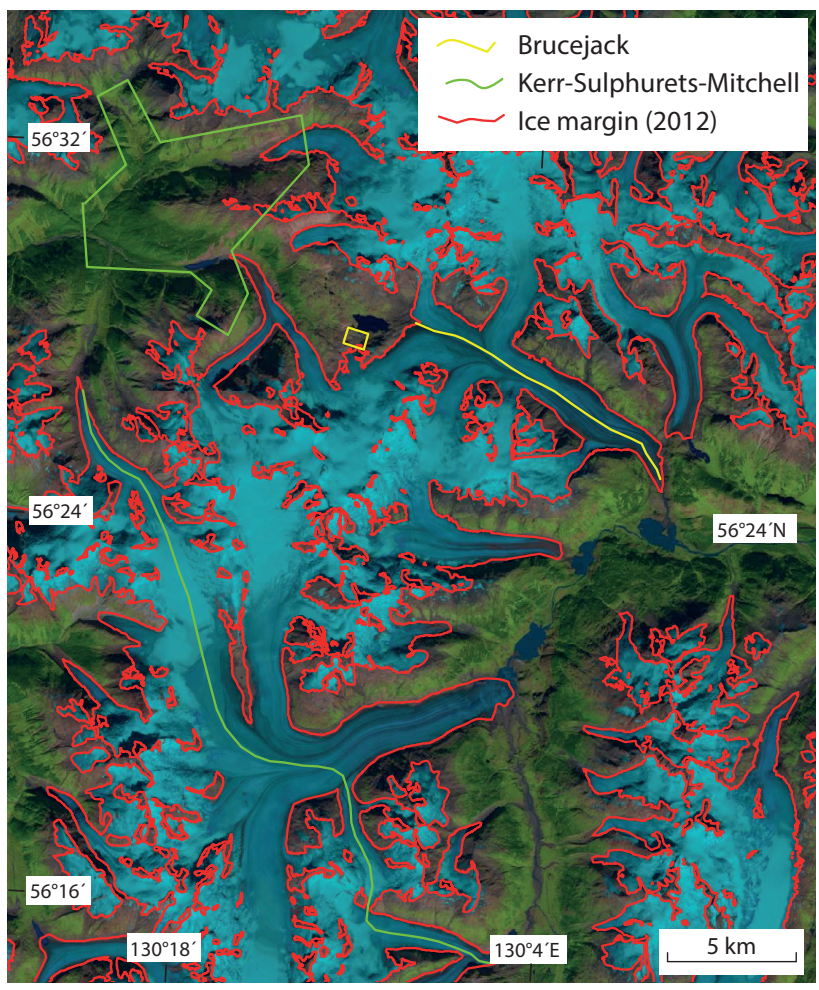

Fig. 4. The potential Kerr-Sulphurets-Mitchell mine in Canada, approved in 2014. Proposed approximate mine area, contemporary ice margins and supraglacial access road. The background is a 2014 Landsat image. The analogous features of the nearby Brucejack prospect are also shown.

erse glaciers even more sensitive to thermodynamic conditions than roads that traverse permafrost areas. Additionally, as a consequence of glacier margin retreat, which can exceed $10 \mathrm{~m}$ per year, approach ramps at the transition from non- to ice-covered terrain require persistent maintenance on a weekly basis during the melt season (Davis 1967).

\section{Summary}

Climate change will further exacerbate the unique applied glaciological challenges associated with proglacial mining described above. Rising atmospheric temperatures are expected to increase the meltwater runoff from the ice sheet by a factor of five by the end of the century (Fettweis et al. 2013). The probability of individual catastrophic supraglacial lake drainage events into the subglacial system is proportional to this summer melt intensity (Liang et al. 2012). As ice rheology, i.e., the relation between stress and strain, is highly temperature dependent, the tremendous latent energy of meltwater can heat the ice and accelerate ice deformation (Phillips et al. 2013). The challenge of maintaining supraglacial road access increases with the length of the melt season 
and surface ablation (Davis 1967). Finally, with glaciers serving as highly visible indicators of climate change, proglacial mining projects often face exceptional public opposition in comparison to conventional hard rock mining projects (e.g. Satke \& Galdini 2014).

As described in this report, the GEUS glaciology group has both a history of providing commercial services for proglacial projects, and a familiarity with the unique challenges confronting future proglacial projects. The glaciology group has carried out extensive research and monitoring programmes in Greenland for more than sixty years. During this time, the glaciology group has developed a broad suite of glaciology-specific instrumentation, including autonomous climate stations that are capable of reporting numerous parameters via satellite link at hourly time intervals. The ongoing Programme for Monitoring of the Greenland Ice Sheet (PROMICE), generates a large amount of climatology and glaciology data, as well as ensures a glaciology group presence for survey and maintenance operations around the ice sheet perimeter. When synergistic, the glaciology group partners with Asiaq (Greenland Survey) on joint projects. In addition to serving as an advisory institute to the Danish Ministry of Climate and Energy, GEUS also serves as a contractually appointed advisory institute to the Greenland Ministry of Mineral Resources.

\section{References}

Ahlstrøm, A., Mottram, R., Nielsen, C., Reeh, N. \& Andersen, S. 2008: Evaluation of the future hydropower potential at Paakitsoq, Ilulissat, W. Greenland. Danmarks og Grønlands Geologiske Undersøgelse Rapport 2008/37, 50 pp.

Arenson, L. and Colgan, W. 2015: Water management challenges associated with mining projects in Greenland, 533-543. Proceedings of Mine Water Solutions in Extreme Environments 2015. Vancouver, Canada.

Braithwaite, R.J. \& Olesen, O. 1988: Effect of glaciers on annual run-off, John Dahl Land, South Greenland. Journal of Glaciology 34, 200-207.

Braithwaite, R.J. \& Thomsen, H.H. 1989: Simulation of run-off from the Greenland ice sheet for planning hydro-electric power, Ilulissat/Jakobshavn, West Greenland. Annals of Glaciology 13, 12-15.

Chandler, D.M. et al. 2013: Evolution of the subglacial drainage system beneath the Greenland ice sheet revealed by tracers. Nature Geoscience 6, 195-198.

Citterio, M., Mottram, R., Larsen S.H. \& Ahlstrøm, A. 2009: Glaciological investigations at the Malmbjerg mining prospect, central East Greenland. Geological Survey of Denmark and Greenland Bulletin 17, 73-76.

Colgan, W. 2014: Considering the ice excavation required to establish and maintain an open ice pit. Journal of Cold Regions Engineering 28, 04014003.

Colgan, W. \& Arenson, L.U. 2013: Open-pit glacier ice excavation: brief review. Journal of Cold Regions Engineering 27, 223-243.

Davis, R.M. 1967: Ice surface movement on the Tuto Ramp in North
Greenland. U.S. Army Cold Regions Research \& Engineering Laboratory Technical Report 164, 24 pp.

Els, F. 2012: You want ice with that? Centerra dives 18\% after saying waste and ice will cut Kumtor production by 200,000 oz. Mining.com, 27 March 2012. http://www.mining.com/you-want-ice-with-that-centerra-dives-18-after-saying-waste-and-ice-will-cut-kumtor-production-by200000-oz.

Fausto, R.S., van As, D. \& the PROMICE project team 2012: Ablation observations for 2008-2011 from the Programme for Monitoring of the Greenland Ice Sheet (PROMICE). Geological Survey of Denmark and Greenland Bulletin 26, 73-76.

Fettweis, X., Franco, B., Tedesco, M., van Angelen, J.H., Lenaerts, J.T.M., van den Broeke, M.R. \& Gallée, H. 2013: Estimating the Greenland ice sheet surface mass balance contribution to future sea level rise using the regional atmospheric climate model MAR. The Cryosphere 7, 469-489.

Joughin, I. Smith, B.E., Howat, I.M. Scambos, T. \& Moon, T. 2010: Greenland flow variability from ice-sheet-wide velocity mapping. Journal of Glaciology 56, 415-430.

Lewis, S.M. \& Smith, L.C. 2009: Hydrologic drainage of the Greenland ice sheet. Hydrological Processes 23, 2004-2011.

Liang, Y.L., Colgan, W., Lv, Q. Steffen, K., Abdalati, W., Stroeve, J., Gallaher, D. \& Bayou, N. 2012: A decadal investigation of supraglacial lakes in West Greenland using a fully automatic detection and tracking algorithm. Remote Sensing of Environment 123, 127-138.

Mayer, C. \& Schuler, T.V. 2005: Breaching of an ice dam at Qorlortossuup tasia, south Greenland. Annals of Glaciology 42, 297-302.

Nye, J.F. 1952: The mechanics of glacier flow. Journal of Glaciology 2, 82-93.

Phillips, T., Rajaram, H., Colgan, W., Steffen, K. \& Abdalati, W. 2013: Evaluation of cryo-hydrologic warming as an explanation for increased ice velocities in the wet snow zone, Sermeq Avannarleq, West Greenland. Journal of Geophysical Research, Earth Surface 118, 1241-1256.

Rennermalm, A.K., Smith, L.C., Chu, V.W., Box, J.E., Forster, R.R., van den Broeke, M.R., van As, D. \& Moustafa, S.E. 2013: Evidence of meltwater retention within the Greenland ice sheet. The Cryosphere 7, 1433-1445.

Satke, R. \& Galdini, F. 2014: EBRD's environmental policy under scrutiny in Kyrgyzstan. The Diplomat, 17 November 2014. http://thediplomat.com/2014/11/ebrds-environmental-policy-under-scrutiny-inkyrgyzstan

Smart, C.C., Owens, I.F., Lawson, W. \& Morris, A.L. 2000: Exceptional ablation arising from rainfall-induced slushflows: Brewster Glacier, New Zealand. Hydrological Processes 14, 1045-1052.

Smith, L.C. et al. 2015: Efficient meltwater drainage through supraglacial streams and rivers on the southwest Greenland ice sheet. PNAS 112, 1001-1006.

Thomsen, H.H., Thorning, L. \& Olesen, O.B. 1989: Applied glacier research for planning hydro-electric power, Ilulissat/Jakobshavn, West Greenland. Annals of Glaciology 13, 257-261.

Thomsen, H.H., Braithwaite, R.J., Weidick, A. \& Olesen, O.B. 1993: Evaluation of hydropower potential for possible future industrial use, Nuuk area, West Greenland. Rapport Grønlands Geologiske Undersøgelse 159, 59-62.

Van As, D. et al. 2014: Increasing meltwater discharge from the Nuuk region of the Greenland ice sheet and implications for mass balance (1960-2012). Journal of Glaciology 60, 314-322.

Weidick, A. \& Thomsen, H.H. 1986: A decade of glacier investigations for utilisation of Greenland hydropower. Rapport Grønlands Geologiske Undersøgelse 128, 157-169.

\section{Authors' address}

Geological Survey of Denmark and Greenland, Øster Voldgade 10,DK-1350Copenhagen K, Denmark. E-mail:wic@geus.dk 